\title{
Wiesław Dębski
}

University of Finanse and Management, Warsaw

e-mail: wdebski@vizja.pl

\section{Ewa Feder-Sempach, Szymon Wójcik}

University of Lodz

e-mails: ewafeder@wp.pl; szymon.wojcik@uni.lodz.pl

\section{STATISTICAL PROPERTIES OF RATES OF RETURN OF THE COMPANIES LISTED ON THE WARSAW STOCK EXCHANGE IN THE PERIOD OF 2005-2015}

\section{WŁASNOŚCI STATYSTYCZNE STÓP ZWROTU SPÓŁEK NOTOWANYCH NA GPW W WARSZAWIE W LATACH 2005-2015}

DOI: $10.15611 /$ ekt.2017.3.07

JEL Classification: G10, G15

Summary: The rates of return of listed companies are subject to numerous studies, particularly those listed on the stock exchange. Information about rates of return are useful primarily for investors choosing an investment, estimating its risk and profitability of the investment made. Among these studies, many of them are devoted to the examination of the statistical properties of the rates of return. The aim of the article is to examine the statistical properties of the monthly rates of return of companies listed on the Warsaw Stock Exchange in the period of 2005-2015. Such parameters as mean value, standard deviation, semi-standard deviation, skewness and kurtosis will be studied, and whether the rates of return have a normal distribution. These properties will be investigated for the whole market and broken down into bull and bear market conditions.

Keywords: rates of return, shares listed on stock exchange, statistical properties, bull and bear market.

Streszczenie: Stopy zwrotu z akcji spółek notowanych na rynku są przedmiotem licznych badań, w szczególności akcji notowanych na rynku giełdowym. Informacje o nich są użyteczne dla inwestorów podejmujących decyzje inwestycyjne, którzy dokonując ich wyboru, szacują między innymi ich ryzyko i opłacalność. Przedmiotem wielu z tych badań są też statystyczne własności stóp zwrotu. Podstawowym celem artykułu jest zbadanie statystycznych własności miesięcznych stóp zwrotu z akcji spółek notowanych na warszawskiej giełdzie w latach 2005-2015. Przedmiotem analizy są takie parametry, jak: wartość średnia, odchylenie standardowe, semiodchylenie standardowe, skos oraz kurtoza, a także normalność rozkładu szeregów stóp zwrotu. Analiza jest prowadzona dla całego rynku oraz w podziale na rynek byka i niedźwiedzia.

Słowa kluczowe: stopy zwrotu, akcje notowane na giełdzie, własności statystyczne, rynek byka i niedźwiedzia. 


\section{Introduction}

The main objective of the article, which we treat as a prelude to further study, is to investigate the statistical properties of the monthly rates of return of the possibly largest number of companies listed on the Stock Exchange in Warsaw in the years 2005-2015. There are going to be studied such descriptive statistics of the rates of return as the arithmetic average, standard deviation and semi-standard deviation, skewness and kurtosis, and it will be checked if the rates of return are subject to normal distribution and if their series are stationary. We will also verify the following hypotheses: a) whether the value of the expected rate of return on the shares of the audited company actually differs from zero, b) whether there is a statistically significant difference between the rate of return the shares of a company and the return on the portfolio of the stock index to which the company belongs and c) whether there is a statistically significant difference between the volatility of the rate of return on the shares of a company and the volatility of the rate of return on the portfolio of the stock index. The study described above will also be carried out on the distribution of the whole market to a bull market and a bear market ${ }^{1}$.

\section{Overview of the subject literature}

The study of the basic statistical properties rates of return of shares of companies, especially those listed on the stock exchange market, is usually a prelude to the further study of the rates of return from shares. In particular, examination of these properties is needed to estimate and analyze the beta parameter in the Sharpe model [Sharpe 1964, pp. 425-442]. Understanding these properties enables the use of the appropriate method for the estimation of the model when assumptions about the distribution of the rate of return or the stochastic structure of the model are not met and we want the estimated beta parameter to meet the assumptions of the best estimator (i.e. is unbiased, consistent and most effective). This is also important for the stability study of this parameter, especially when the entire period of the statistical sample is divided into sub-periods of growth (bull market) and falls (bear market) and the Sharpe model estimation runs separately for the two periods.

Around the world, numerous empirical studies on the statistical properties of the rates of return from shares have been carried out for many years. Among them we can point out the study conducted by A. Corhay and A. Tourani Rad [1994, pp. 271-282]. Analysis of the daily rates of return from shares held by European indexes pointed to the presence of, among others, such phenomena as skewness, leptokurticity and heteroskedasticity. Another study [Harrison, Lupu, Lupu 2010, pp. 41-54] conducted on the way international markets affected the daily rates of return

\footnotetext{
${ }^{1}$ The full description of the conducted research is included in CEST2015 Proceedings, ISBN 8389588-46X, Lodz 2016, available on www.cest2015.uni.lodz.pl
} 
Wiesław Dębski, Ewa Feder-Sempach, Szymon Wójcik

from shares on ten markets of Central and Eastern Europe in the period 1994-2006. The results indicated stationarity of the series rates of return, their independence and cross-correlation. A study of the distribution of monthly rates of return of the shares from the US market can be mentioned here conducted by R. Officer [1972, pp. 807--812], who showed that the basic feature of the analyzed distributions were fat tails, but same distribution was characterized by stability in a period of up to five months.

The results of empirical studies relating to the basic statistical properties of the rates of return from shares, as well as in connection with the estimation and analysis of the beta parameter can also be found in many publications, for example: [Dębski, Feder-Sempach 2012, pp. 90-102; Feder-Sempach 2011; Kompa, MatuszewskaJanica 2008, pp. 614-629; Schwert, Seguin 1990, pp. 1129-1155; Tarczyński, Witkowska, Kompa 2013].

\section{Description of the research sample}

For the studies there were selected shares of the largest companies listed on the Warsaw Stock Exchange in the period 2005-2015 (30 September 2015), for which data from this period were complete. The data comes from the Thomson Reuters service. There were collected data on monthly returns for 131 companies that have been assigned to individual indices defined by the Exchange in accordance with the market capitalization. In accordance with the division 12 companies belong to the WIG20 index, 25 companies to the mWIG40 index, 30 stocks to sWIG80 and the remaining 64 companies to the WIGPlus index ${ }^{2}$. More interesting from the cognitive point of view could be the division of companies according to the adopted by the stock exchange classification of economic sectors, however, not each of them has a suitable stock market subindex from which the rate of return would be needed as a reference to verify the hypotheses posed in the article. So the entire database for 131 companies contains 130 observations of the monthly rate of return calculated using the closing price on the last day of the month, i.e. from 31 December 2004 to 30 September 2015. The rates of return are calculated without taking into account revenues from dividends according to the following formula:

$$
R_{i t}=\left(\ln P_{i t}-\ln P_{i t-1}\right) \times 100
$$

where: $R_{i t}$ - monthly logarithmic rate of return of the $i$-th share in the period $t(\mathrm{in} \%)$, $P_{i t}$ - price of the $i$-th share in period $t$.

2 The WIGPlus index complements the WIG20, mWIG40 and sWIG80 indexes. It consists of companies that are not eligible for the above-mentioned indices and at the same time belong to the 5PLUS segment, which means that their average market value in the last quarter is in the range of 5 to 50 million euros. 
For the thus defined research sample, first there were calculated basic descriptive statistics of the rates of return and then the research hypotheses were verified, referred to in the introduction. These calculations are a prelude to more advanced studies, e.g. relating to the beta parameter which will be done later on. To perform the current calculations we used the STATA program.

The main problem in all analyzes relating to the beta parameter conducted on longer samples (over 5 years) is the division of the analyzed period to a growth market (bull market) and declining market (bear market). An extensive study on the division of the stock market to a bull and bear market was proposed by A. Pagan and K. Sossounov [Pagan, Sossounov 2003, pp. 23-46]. The authors have undertaken some key issues related to the division of the market, which is used in various economic studies, e.g. relating to business cycles. They demonstrated the basic definitions of a bull and bear market and the main algorithms according to which this division is being made.

In this article we decided to use the so called Peak and Trough Method (see: [Dębski, Feder-Sempach 2012, pp. 90-102]). This method is based on the use of a moving average of the rate of return from the market index in the period $t\left(r_{m t}\right)$. This method identifies two moments which are peak and trough. The peak in the period $(\mathrm{t})$ is defined when:

$$
\left\{r m_{t-2}, r m_{t-1}\right\}<r m_{t}>\left\{r m_{t+1}, r m_{t+2}\right\}
$$

and a trough in the period $(\mathrm{t})$ when:

$$
\left\{r m_{t-2}, r m_{t-1}\right\}>r m_{t}<\left\{r m_{t+1}, r m_{t+2}\right\}
$$

After identifying the peak and the trough, the period between the trough and the peak is classified as a bull market and the period between the peak and the trough as a bear market [Bhaduri, Durai 2006, p. 57].

This method is often used in empirical studies and meets some of the assumptions made by the above-mentioned Pagan and Sossounov. The division was made according to the method based on the points of intersection of the 14-day moving average with the WIG stock exchange index, which is shown in Figure 1. We adopted the 14-day moving average because it most fully reflects changes in the WIG index in the studied period.

According to accepted definition periods, those classified as a bull market gave us 99 observations, while periods classified as a bear market 31 observations. 
Wiesław Dębski, Ewa Feder-Sempach, Szymon Wójcik

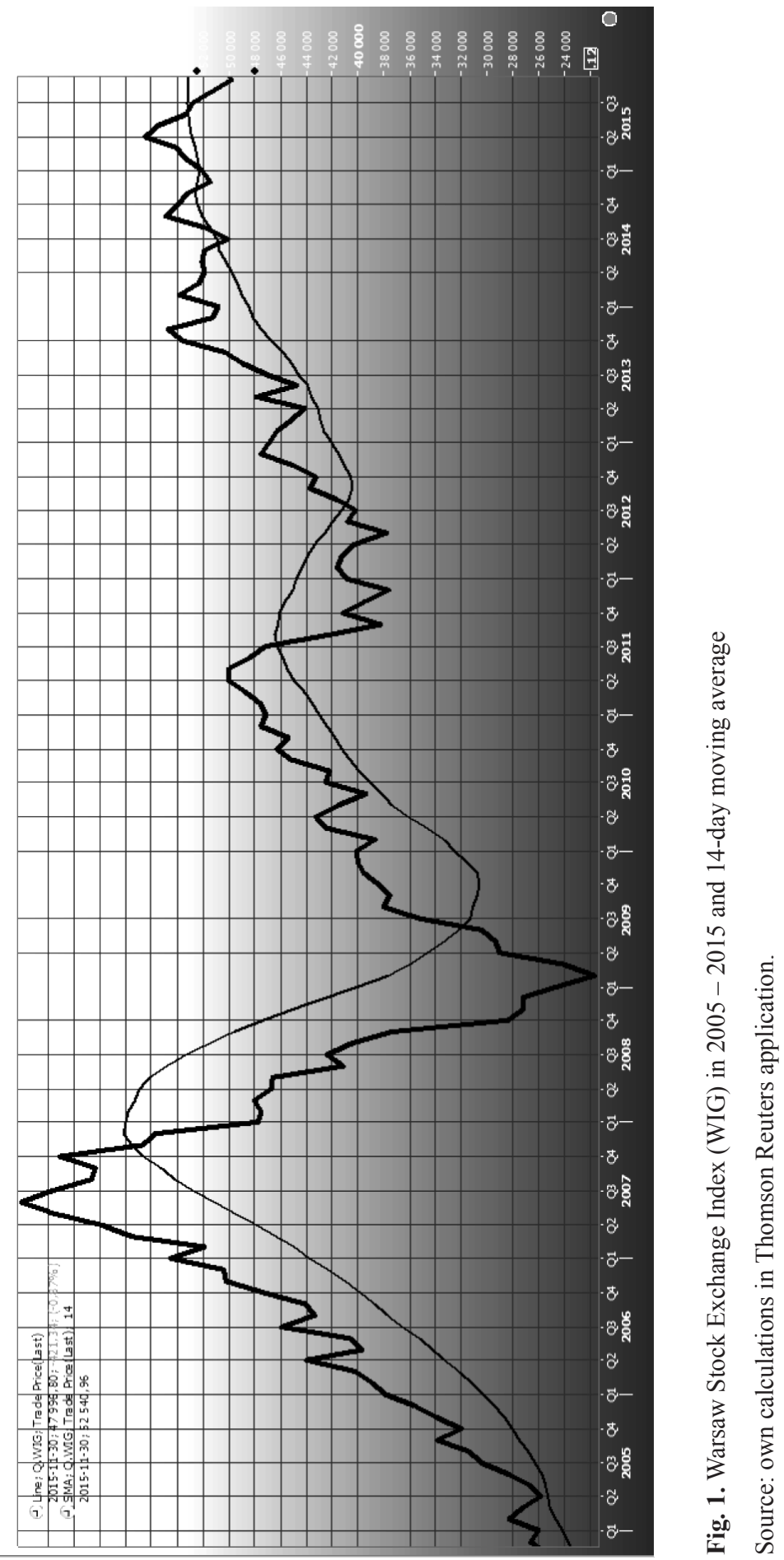




\section{Discussion on the obtained results of the empirical research}

As written in the introduction, firstly objects of study are the basic statistical properties of the monthly logarithmic rate of return from the shares of 131 companies listed on the Stock Exchange in Warsaw in the period 2005-2015 (the end of the third quarter). These properties were investigated by calculating basic descriptive statistics, which are: arithmetic average $(\bar{R})$, standard deviation (S), semi-standard deviation (SS), skewness (A) and kurtosis (K). Subsequently the normality of logarithmic distribution of the monthly rate of return of surveyed companies and stationarity of its time series was subjected to statistical verification as well as hypotheses relating to the alignment of the rate of return of the surveyed company to zero and the rate of return of the corresponding stock index and whether there is a statistically significant difference between the volatility of the rate of return of a given company and the volatility of the stock index rate of return ${ }^{3}$. These calculations were made in the division of companies to the earlier indicated indices defined by the Warsaw Stock Exchange.

\subsection{Results relating to the whole sample}

The values of descriptive statistics of the rates of return from the shares of companies classified as the WIG20 index portfolio (12 companies) are shown in Table 1. As we know, this index includes companies with the largest market capitalization from the Warsaw Stock Exchange.

Table 1. Descriptive statistics of the rates of return of the WIG20 index

\begin{tabular}{|l|c|c|c|c|c|l|}
\hline \multicolumn{1}{|c|}{ Company } & $\bar{R}$ & $\mathrm{~S}$ & $\mathrm{SS}$ & $\mathrm{A}$ & $\mathrm{K}$ & \multicolumn{1}{c|}{ Sector } \\
\hline PGNIG & 0.4970 & 7.1737 & 4.9610 & 0.0335 & 0.0732 & Oil \& Gas \\
\hline PEKAO & 0.0870 & 8.9809 & 6.4843 & -0.1448 & 3.3442 & Banking \\
\hline PKOBP & 0.1065 & 8.8163 & 6.7567 & -0.8586 & 3.3611 & Banking \\
\hline BZWBK & 0.8583 & 9.8055 & 6.9486 & 0.0254 & 1.4788 & Banking \\
\hline PKNORLEN & 0.4344 & 8.5566 & 6.3549 & -0.3657 & 0.0169 & Oil \& Gas \\
\hline KGHM & 0.9148 & 12.4319 & 9.2832 & -0.6663 & 2.2250 & Basic Materials \\
\hline MBANK & 0.9595 & 11.6120 & 9.0083 & -1.0764 & 4.1520 & Banking \\
\hline LPP & 2.0843 & 11.4691 & 8.7034 & -0.7563 & 3.1530 & Retail trade \\
\hline ORANGEPL & -0.7767 & 9.0154 & 7.3121 & -2.1153 & 11.0572 & Telecommunication \\
\hline EUROCASH & 2.0612 & 8.9143 & 6.2884 & -0.0965 & -0.2345 & Retail trade \\
\hline SYNTHOS & 1.4172 & 12.4241 & 8.9549 & -0.1983 & 0.7462 & Chemicals \\
\hline ASSECOPOL & 0.5138 & 7.8680 & 5.3328 & 0.1696 & 1.8768 & IT \\
\hline
\end{tabular}

Explanatory note: The values of kurtosis are reported as excess kurtosis (i. e. for normal distribution they are equal to 0 ).

Source: own calculations.

${ }^{3}$ Formulas for these statistics, as well as tests for verification of the hypotheses mentioned in the article can be found, inter alia, in: [Tarczyński, Witkowska, Kompa 2013]. 
This shows that the arithmetic average of the logarithmic monthly rates of return of the whole period (2005-2015) for all companies (except one) adopts positive values, including 8 companies where there are values less than 1 . In turn, the volatility expressed as a standard deviation (S) is very high, because all companies exceed the value 7 . Volatility measured by a semi-standard deviation (SS) is lower due to the fact that the calculation of the semi-deviation covers only the negative deviations from the average. This large volatility is caused by several periods of growth and decline of the stock index, which can be seen in Figure 1. The tested distribution of the rates of return for the vast majority of companies (for 9 of the 12) has the negative asymmetry ( $\mathrm{A}$ is the given statistics standardized measure), this asymmetry, however, is not generally high. The values of kurtosis indicate that the distributions of the logarithmic rates of return for all companies (except one) are leptokurtic (for some companies there is a high concentration around the average). In two cases it can be concluded that the distribution of the monthly logarithmic rate of return is normal (companies belonging to the oil sector).

For the companies from the mWIG40, sWIG80 and WIGPlus indexes, the same studies were carried out as for companies from the WIG20 index. The results indicate that the highest percentage of the companies from the mWIG40 index as well as the sWIG80 index has a positive arithmetic average of the monthly logarithmic rates of return but not exceeding 1 (respectively $48 \%$ and $53 \%$ ) while for the companies from the WIGPlus index, for $45 \%$ of companies this average has a negative value. A similar average value as the companies from the mWIG40 and sWIG80 indexes had the companies from the WIG20 index. It is worth noting that $88 \%$ of the companies from the mWIG40 index and $73 \%$ of the companies from the sWIG80 index have a positive arithmetic average. Regarding the investment risk (measured by a standard deviation) the largest percentage of companies of all indexes has a risk at the level of 10-15. The same applies to the semi-standard deviation, except that its value (which is understandable) is lower (since it is contained in the range of 7 to 10). It is also worth noting that the percentage of the companies from the mWIG40 index having the values of S and SS of the above ranges is higher $(56 \%$ and $60 \%)$ than the percentages of the companies from the sWIG80 and the WIGPlus indexes (respectively $46 \%$ and $37 \%$ as well as $53 \%$ and $47 \%$ ), which would mean that the variability of the rates of return of the companies from the mWIG40 index (and therefore larger in terms of the market capitalization) is higher. On the other hand we can say that $64 \%$ of the companies with the mWIG40 and sWIG80 indexes have no asymmetry in the distribution of the rate of return (the values of $\mathrm{A}$ are in the range from -0.5 to 0.5 ). For the companies from the WIGPlus index this is $45 \%$ of the companies. For this index, $42 \%$ of the companies have right-sided asymmetry above 0.5 . The obtained values kurtosis indicate that the vast majority of companies belonging to all indices have a series of the rates of return more concentrated around the average than the normal distribution (kurtosis values greater than 1). However, it is worth noting that $32 \%$ of the companies from the mWIG40 index and $23 \%$ of 
the companies from the sWIG80 index has a distribution similar to a large extent to a normal distribution. We can venture to say that the larger the company, the higher the percentage of the companies from the relevant index with a distribution close to normal.

Assumption of normality of distribution was tested using the common tests of Jarque-Bera and Shapiro-Wilk. According to both applied tests the distribution of the monthly logarithmic rate of return from shares for 8 companies belonging to the WIG20 index is not a normal distribution. In fact, this study confirms the results presented in Table 1 referring to asymmetry and also for the kurtosis in relation to the PGNiG and PKNORLEN companies. Normality tests conducted for the companies from the mWIG40, sWIG80 and WIGPlus indexes indicate that in the vast majority of companies (over 64\% for the level of significance of 0.05 ), the distribution of the rates of return is not a normal distribution, while for companies with smaller market capitalization this percentage increases (e.g. to almost $86 \%$ for the companies from the WIGPlus index). We may also note that the two applied tests brought very similar results.

The stationarity of time series was also tested in our study. On the basis of augmented Dickey-Fuller test, we can conclude that for all the examined companies belonging to all of the surveyed indexes, a series of the monthly logarithmic rate of return from shares is a stationary series. This means that there should not be any major complications in the correct estimation of the beta parameter as well as its basic characteristics, for example the measure of dispersion.

In a later step of the research this was subjected to the statistical verification of the hypothesis whether the expected rate of return from the shares of the surveyed company is significantly different from zero and whether the expected rate of return is significantly different from the rate of return from the stock market index to which the company was classified. In the latter case, we test whether there is a statistically significant difference in the two series of the rates of return. The values presented in the table indicate that the expected monthly logarithmic rate of return from shares for 10 out of 12 companies does not differ significantly (for the level $\alpha=0.05$ ) from zero, and also this rate for 10 out of the 12 companies is not significantly different from the expected rate of return from the WIG20 index. From the results obtained for all the remaining indexes, we can conclude that the company has a higher market capitalization including the percentage of rejection of the null hypothesis of the equal rate of return of zero or the rate of return of the relevant index is higher.

The last verified hypothesis was the hypothesis of equality between the variances of the monthly logarithmic rate of return from the shares of a given company and the variance of the rate of return from the stock market index to which the company is classified. The verification of such formulated hypothesis is made on the basis of the statistics of the Fisher-Snedecor test. The obtained results indicate that for almost all companies, we propose to reject the null hypothesis saying that the volatility of the monthly logarithmic rate of return from the shares of companies belonging to the 
WIG20 index does not differ from the volatility of the rate of return from the index, which means that the volatilities are different. The results for all the remaining indexes show that over $90 \%$ of companies (for $\alpha=0.05$ ) the variance of the rate of return of the company is significantly different from the variance of the rate of return of a given stock index.

\subsection{The results for the division of the market into a bull and bear market}

According to paragraph 3 of the article, the period of the entire study sample was divided into a bull market period (99 observations) and a bear market period (31 observations). For both periods we performed the same empirical study that for the whole period, and therefore we calculated the basic descriptive statistics of the rates of return of the surveyed companies and examined whether the time series are normally distributed and are stationary. The results, divided into companies belonging to the WIG20, mWIG40, sWIG80 and WIGPlus indexes are described below, whereby first there are presented the descriptive statistics of the rates of return of the companies belonging to the WIG20 index (Tables 2 and 3).

Table 2. Descriptive statistics of the rates of return of the WIG20 index in the period of a bull market

\begin{tabular}{|l|c|c|c|c|c|l|}
\hline \multicolumn{1}{|c|}{ Company } & $\bar{R}$ & $\mathrm{~S}$ & $\mathrm{SS}$ & $\mathrm{A}$ & $\mathrm{K}$ & \multicolumn{1}{c|}{ Sector } \\
\hline PGNIG & 0.9921 & 6.6788 & 4.4216 & 0.2789 & -0.1700 & Oil \& Gas \\
\hline PEKAO & 1.0286 & 6.7570 & 4.7860 & 0.0500 & 0.3933 & Banking \\
\hline PKOBP & 1.0694 & 6.7055 & 4.6392 & 0.3344 & 0.8809 & Banking \\
\hline BZWBK & 2.1505 & 8.6014 & 5.5905 & 0.6326 & 1.4735 & Banking \\
\hline PKNORLEN & 1.5470 & 7.6745 & 5.4995 & -0.1356 & -0.1097 & Oil \& Gas \\
\hline KGHM & 1.7339 & 9.7828 & 6.7844 & 0.1400 & -0.0869 & Basic Materials \\
\hline MBANK & 2.4610 & 8.0891 & 5.5250 & 0.1290 & -0.0370 & Banking \\
\hline LPP & 3.0469 & 10.6125 & 7.4652 & -0.0344 & 1.3425 & Retail trade \\
\hline ORANGEPL & -0.5432 & 9.9611 & 8.1673 & -2.1376 & 9.6160 & Telecommunication \\
\hline EUROCASH & 2.3981 & 8.0072 & 5.3883 & 0.1656 & -0.5647 & Retail trade \\
\hline SYNTHOS & 2.3624 & 10.5025 & 7.3705 & -0.1622 & 1.5900 & Chemicals \\
\hline ASSECOPOL & 1.0663 & 7.3907 & 4.8674 & 0.4115 & 1.3228 & IT \\
\hline
\end{tabular}

Source: own calculations.

Tables 2 and 3 show that the absolute values of the arithmetic average for the companies are higher for a bull market (more positive) as well as for a bear market period (more negative) than for the entire market, which is a normal phenomenon. Received measurements of dispersion (standard deviation and semi-standard deviation) during a bull market are lower (sometimes significantly) with respect to the measurements obtained for the entire market. In contrast, these measurements 
Table 3. Descriptive statistics of the rates of return of the WIG20 index in the period of bear market

\begin{tabular}{|l|c|c|r|r|r|l|}
\hline \multicolumn{1}{|c|}{ Company } & \multicolumn{1}{c|}{$\bar{R}$} & \multicolumn{1}{c|}{$\mathrm{S}$} & \multicolumn{1}{c|}{ SS } & \multicolumn{1}{c|}{$\mathrm{A}$} & \multicolumn{1}{c|}{ K } & \multicolumn{1}{c|}{ Sector } \\
\hline PGNIG & -1.0679 & 8.4861 & 5.9943 & -0.1452 & -0.1937 & Oil \& Gas \\
\hline PEKAO & -2.8895 & 13.5816 & 9.0571 & 0.3081 & 1.5637 & Banking \\
\hline PKOBP & -2.9374 & 13.1776 & 10.0133 & -0.7255 & 0.6291 & Banking \\
\hline BZWBK & -3.2269 & 12.1785 & 8.9419 & -0.1348 & 0.2305 & Banking \\
\hline PKNORLEN & -3.0830 & 10.2529 & 7.4309 & -0.2476 & -0.7388 & Oil \& Gas \\
\hline KGHM & -1.6744 & 18.4625 & 13.7753 & -0.6395 & 0.4294 & Basic Materials \\
\hline MBANK & -3.7872 & 18.2508 & 13.7462 & -0.5841 & 0.6679 & Banking \\
\hline LPP & -0.9587 & 13.5824 & 11.2214 & -1.6463 & 3.4729 & Retail trade \\
\hline ORANGEPL & -1.5148 & 5.0221 & 3.4185 & 0.3235 & 0.1115 & Telecommunication \\
\hline EUROCASH & 0.9963 & 11.4106 & 8.2132 & -0.2439 & -0.6241 & Retail trade \\
\hline SYNTHOS & -1.5708 & 17.0236 & 11.5862 & 0.1235 & -0.6489 & Chemicals \\
\hline ASSECOPOL & -1.2328 & 9.1306 & 6.2433 & -0.0457 & 2.1394 & IT \\
\hline
\end{tabular}

Source: own calculations.

for a bear market period are much higher than for the entire market. Distributions of the rates of return during a bull market are characterized by a generally positive asymmetry, while during the bear market almost all companies (except three) have a distribution of the rate of return with a slight negative asymmetry. Kurtosis values of the vast majority of companies in both distinguished markets are positive, which means that the distributions of the rates of return are more concentrated around the average (leptokurtic). When kurtosis assumes a negative value (several companies) then its value is not less than -0.74 . For the entire market the values of kurtosis for all companies (except one) were positive.

While for the entire market the values of the arithmetic average from the range $[0 ; 1]$ were from $41 \%$ (WIGPlus indexes) to 53\% companies (sWIG80), currently there have been significant shifts, i.e. for a bull market from $67 \%$ (WIGPlus) to $88 \%$ (mWIG40) companies have an average value greater than 1 and for a bear market from $84 \%$ (mWIG40) to $98 \%$ (WIGPlus) has an average value of less than zero. Similar shifts can be observed in terms of dispersion measures, i.e. in a bull market there is bigger percentage of companies (except the WIGPlus index) for which the standard deviation is in the range of $[0 ; 10)$ and in a bear market a greater percentage of companies for which the deviation is larger (is in the range of $(15,+\infty)$ values of the semi-standard deviation show that there was definitely an increased percentage of companies with the deviation from the range of $[0 ; 7)$ for a bull market and percentage of companies for which the deviation is greater than 10 for a bear market. In turn, the asymmetry index indicates that for larger companies (from the mWIG40 index) the distribution of the rates of return is characterized by a very low skewness, both for a bull market and a bear market (respectively $72 \%$ and $64 \%$ of companies 
have asymmetry from the range of $[-0.5,0.5]$. Similar asymmetry characterized distributions of the rates of return for the companies from that index for the entire market. A significant positive asymmetry characterizes the distributions of the rates of return of small companies (from the WIGPlus index), because their percentage is $65 \%$ in a bull market. As far as the kurtosis, over half of the companies (except the WIGPlus index in a bull market) has a distribution substantially similar to normal (kurtosis ratio is in the range of $[-1,1]$ ). Noteworthy is the $87 \%$ from the WIGPlus companies for which the rates of return have leptokurtic distribution in a bull market (in a bear market with such distribution of the rates of return there is only $41 \%$ of companies).

Normality tests were also conducted for indexes divided into a bull and bear market. The results for the WIG20 showed that in the vast majority of cases in both types of markets there is no basis to reject the null hypothesis, saying that the rate of return distribution is a normal distribution. For a bull market fractions, rejecting the null hypothesis saying that the distribution of the rates of return from shares of a given company belongs to a normal distribution are relatively high (for the companies from the WIGPlus index it is in fact more than $87 \%$ for the level of significance of 0.05 ). It should be noted that the greater the companies' market capitalization, the smaller the percentage rejecting the null hypothesis (for the sWIG80 it is almost 57\%, and for the mWIG40 index 40\%). Whereas for a bear market fractions rejecting the null hypothesis are much lower (for the level of significance of 0.05 they amount to in fact from $20 \%$ to $30 \%$ ). In turn, on the basis of statistics of the stationarity test it is shown that for all companies in the periods of both of the distributions of the rates of return (at the level of significance of 0.05) are stationary (the same attribute was found for the entire market).

The results of testing the hypotheses about the equality of the rates of return from shares of the companies belonging to the WIG20 index for a bull and bear market indicate that the expected monthly logarithmic rate of return for 6 companies in a bull market and all 12 for a bear market is not significantly different (for $\alpha=0.05$ ) from zero. This rate also does not differ significantly (except for three cases for a bull market) from the expected rate of return from the portfolio of the WIG20 index. Similar results were also obtained for the whole market. The smallest fractions rejecting of the null hypothesis in a bull market were obtained for companies with the smallest market capitalization (companies from the WIGPlus index). On the other hand, in a bear market the situation is reversed, because the smallest fractions of rejections of the null hypothesis were obtained for the companies belonging to the mWIG40 index, hence for companies with the highest market capitalization among the companies constituting the portfolio of the three studied indexes. We can also see that the vast majority of companies for both a bull and bear market their expected rates of return from stocks differ significantly in statistical terms from the expected rate of return from the index portfolio to which the company belongs. The highest obtained fraction of rejections of the null hypothesis is $12 \%$ (with $\alpha=0.05$ ) for the 
companies from the mWIG40 index for a bear market. The fraction of rejections of the null hypothesis for the companies from the WIG20 index for a bull market was $25 \%$ and for a bear market $0 \%$. It is impossible to draw a clear conclusion that with the increase of the company's market capitalization the fraction of rejections of the null hypothesis about the equality of the expected rate of return from shares of a given company with an expected rate of return from the index portfolio increases or decreases.

Verification of the hypothesis about the equality of the variance of the logarithmic monthly rate of return from shares of a company belonging to the WIG20 index and the variance of the rate of return from the WIG20 portfolio divided into a bull and bear market was also conducted. This indicates that for a bull market these variances (or volatility) are different for all companies (for $\alpha=0.05$ ), while for a bear market the variances are different for 7 out of the 12 companies. The results for a bull market are very consistent with the results for the whole market. The results for other indices show that for a bull market in the vast number of companies volatilities are different (the smallest fraction of rejections of the null hypothesis is $90 \%$ - companies from the sWIG80 index). We can see that the fraction of rejections of the hypothesis of the equality of variation for the largest companies (from WIG20 and mWIG40) for a bull market is $100 \%$ (for $\alpha=0.05$ ). For a bear market, fractions of rejections of the null hypothesis are significantly lower than for a bull market, while the lower market capitalization of the company the higher the fraction of rejections of the null hypothesis (for the companies from the mWIG40 this index amounts to 52\%).

\section{Summary}

In conclusion, on the carried out research it must be admitted that it brought quite interesting in cognitive terms results, although, judging by the results of research of other authors, we could expect such results. In this sense, the results obtained are to a large degree consistent with the results of other Polish authors however, obtained in slightly different configurations of the time sample or frequency measurement of the rate of return. It should be noted that in our study the sample consisted of 131 companies and 130 monthly observations, making it the largest and longest out of the previous studies relating to the Polish market. The general conclusion to be drawn from the conducted research amounts to saying that it is worth dividing the market into periods of growth and decline ( having a sufficiently long sample) because the distributions of the rates of return have slightly different properties than for the entire market and values of their descriptive statistics change. We have found that for a relatively large proportion of companies, distributions of the rates of return do not have a normal distribution (although they do not have high asymmetries mainly it is in the range $[-1,1])$, and are generally quite concentrated around the mean (leptokurtic), wherein it was found that for larger companies the fraction of rejections of the null hypothesis of normal distribution of the rate of return from 
shares decreases. In contrast, the undoubtedly positive feature is the fulfillment of assumptions about the stationarity of distribution of the monthly logarithmic rate of return for all companies, which presents a great hope for the positive statistical properties of the results of further studies, in particular relating to the beta parameter. On the other hand, the test results of verification for the entire market hypothesis of the equality of the rate of return from shares of a given company with zero or the rate of return from the index portfolio to which a company belongs, indicate that the percentage of rejection of the null hypothesis increases with the market capitalization of the company. But we cannot draw such a clear conclusion just on the basis of verification of these hypotheses for a bull and bear market. As regards the verification of the hypothesis on the equality of the variance of the rate of return from shares with the variance of the rate of return from the index portfolio to which the company belongs, it is unambiguously stated that these variances indeed in statistical terms are different for the vast number of companies, both for the entire market as well as divided into a bull and bear market.

\section{Bibliography}

Bhaduri S., Durai S., 2006, Asymmetric beta in bull and bear market conditions: Evidence from India, Applied Financial Economics Letters, 2.

Corhay A., Tourani Rad A., 1994, Statistical Properties of daily returns: Evidence from European stock markets, Journal of Business Finance and Accounting, vol. 21, issue 2, pp. 271-282.

Dębski W., Feder-Sempach E., 2012, Beta coefficients of Polish Blue Chip Companies in the period of 2005-2011, Folia Oeconomica Stetinensia, 12(20), pp. 90-102.

Feder-Sempach E., 2011, Ryzyko inwestycyjne. Analiza polskiego rynku akcji, CeDeWu, Warszawa.

Harrison B., Lupu R., Lupu I., 2010, Statistical properties of the CEE stock market dynamics. A panel data analysis, The Romanian Economic Journal, September, no. 37, pp. 41-54.

Kompa K., Matuszewska-Janica A., 2008, Charakterystyki opisowe i efektywność informacyjna wybranych instrumentów notowanych na GPW, [w:] Tarczyński W. (ed.), Rynek kapitałowy. Skuteczne inwestowanie, Studia i Prace Wydziału Nauk Ekonomicznych i Zarządzania, nr 9, Uniwersytet Szczeciński, Szczecin, pp. 614-629.

Officer R., 1972, The distribution of stock returns, Journal of American Statistical Association, December, vol. 67, no. 340, pp. 807-812.

Pagan A.R., Sossounov K.A., 2003, A simple framework for analyzing bull and bear markets, Journal of Applied Econometrics, vol. 18, pp. 23-46.

Schwert S., Seguin P.J., 1990, Heteroscedasticity in stock returns, Journal of Finance, vol. 4, pp. 1129-1155 .

Sharpe W.F., 1964, Capital assets prices: A theory of market equilibrium under condition of risk, Journal of Finance, vol. 19, no. 3, September, pp. 425-442.

Tarczyński W., Witkowska D., Kompa K., 2013, Współczynnik beta. Teoria i praktyka, Pielaszek Research, Warszawa. 